\title{
The Effect of Cooperative Integrated Reading and Composition on Reading Comprehension of IAIN Lhokseumawe, Indonesia
}

Erlidawati $^{1 *}$, Syarfuni ${ }^{2}$

${ }^{1}$ English Departement, FKIP IAIN Lhokseumawe, Aceh Utara. Indonesia

${ }^{2}$ English Departement, STKIP Bina Bangsa Getsempena Banda Aceh, Indonesia

Corresponding Author: Erlidawati, E-mail: erlidawati273@gmail.com

\section{ARTICLE INFO}

Article history

Received: March 21, 2018

Accepted: July 01, 2018

Published: August 31, 2018

Volume: 9 Issue: 4

Advance access: July 2018

Conflicts of interest: None

Funding: None

\section{Key words:}

Cooperative Integrated Reading and

Composition (CIRC),

Reading Comprehension,

IAIN Lhokseumawe,

Teaching Reading,

Traditional Method (TM)

\begin{abstract}
This study was conducted to investigate the effect of Cooperative Integrated and Composition (CIRC) in teaching reading comprehension to the third semester students of English departement at IAIN Lhokseumawe. The population of this study was all the students in the third semester and the samples are unit- 1 and unit-2. The sample was chosen by using random sampling technique. The sample consists of 31 and 32 students. To obtain the data, the pre-test and the post-test were given to two groups; experimental group and control group. The instrument used to collect the data was a test. It was used to see learning achievement of students in reading comprehension. The mean score of experimental group was 81,45 by it was 76,09 of control group. Students' reading ability in both groups was different as indicated by the t-test. The $t$-test result shows that the score is 2.210 while the result of t-table is 0,031 at the level of significance is $5 \%(\alpha=0.05)$. Therefore, the alternative hypothesis $\left(\mathrm{H}_{\mathrm{a}}\right)$ is accepted and the null hypothesis $(\mathrm{Ho})$ is rejected. Furthermore, the finding of this study showed that CIRC more effective in In enhancing the students' reading comprehension. This study contributes to further implications for research on language learning strategies, material design and teacher education in English language teaching.
\end{abstract}

\section{INTRODUCTION}

In enriching English learning, it is necessary to acquire four basic skills; listening, speaking, reading, and writing. Reading is one of English skill mostly needed to be mastered by the students from junior high school up to university level. Reading is a process whereby one looks at the text and understands what has been written. Rivers (1999:245) states that reading is the most important activity in any language class, not only as a source of information and a pleasurable activity, but also as a mean of consolidating and extending ones' knowledge of the language, Which students have a proficiency in language. Students are expected to develop their knowledge concerning to a specific context given to them to learn and they are able to comprehend meaning from specific cues in the text.

The unsatisfactory outcome of the teaching reading comprehension in IAIN which is frequently integrated with vocabulary, in general, seems to be caused by many factors. The first factor is related to the lacks of vocabulary, most of the time in the classroom is frequently used up for developing vocabulary translation. The second factor is related to the sources of reading which are sometimes not varied and inappropriate for the students' capabilities. Therefore, the students cannot comprehend the meaning from the text in detail since the students do not have enough background knowledge about the contents of the given text. It often happens because the reading text contains many topics which the students are mostly unfamiliar with students' capability. The third factor is that the English teachers do not possess enough knowledge of their students' need in reading. Besides, the strategies, methods and approaches used by teachers are not interesting or most teachers are still using traditional methods.

In teaching reading comprehension at IAIN English lecturers are asked to prepare their students with a good foundation of reading skills to get main idea, specific information, word meaning and references. Based on curriculum 2008, the students are expected to have in adequate proficiency in reading comprehension and to prepare the students to be able in comprehending text.

Reading process requires continuous practice and development. So, when the students read the text, they can do some ways. First, they can read the text quickly to find out what is it in the text all about. At this stage they do not have to pay 
attention to every single word. Second, after they read the text then they can understand the main ideas of the text and what is a suitable topic for the text. They do not need to know the meaning of every single word to improve their comprehension through the text by speed reading. But if they think a new word is important, the students can identify the word whether it is a verb, noun, or adjective. Then if they want to know the meaning, they can use a dictionary. Third, the students can read the text two or three times and look for the most important pieces of information, keywords and key sentences and mark them. The last, the students have to make a conclusion and the students can give their idea after they read the text.

Reading comprehension is one of the skills in English that have to be studied by the students and they have to understand the content of the text. In previous teaching reading at English department the teacher only teaches reading by the traditional method. The teacher gives the text for students, then they read the text, translate it, and the last they answer the questions. So, the students cannot comprehend the text well, they only know how to answer the question. It is still a problem for the students to understand all the complete meaning of and the message delivered in the text.

According to Steven, at el (2005: 18), Cooperative Integrated Reading and Composition model, used in grades $2-8$, is a cooperative learning program that involves a series of activities derived from research on reading comprehension and writing strategies. Students work in four-member heterogeneous learning team. After the teacher introduces a story from a basal text or trade book, students work in their teams on a prescribed series of activities relating to the story. These include partner reading, where students take turns reading to each other in pairs; "treasure hunt" activities, in which students work together to identify character, settings, problems, and problem, and problem solutions in narratives; and summarization activities. Students write "meaningful sentences" to show the meaning of new vocabulary words, and write compositions that related to their reading. Further, when a child wants to be a student, she or he must have two skills; reading and writing.

\section{Research Objective}

The objectives of the study to find out whether any difference between students' reading comprehension who are taught via Cooperative Integrated Reading and Composition (CIRC) and those who are taught by using Traditional Method (TM)

\section{Research Problem}

Is there any difference between students' reading comprehension who are taught via Cooperative Integrated Reading and Composition (CIRC) and those who are taught by using Traditional Method (TM)?

\section{LITERATURE REVIEW}

\section{Teaching Reading Skill}

The teaching of practicing reading skill aims at helping the students to be active readers who see the reading as a useful need for their own purposes. This section describes ways to activate the students' thought before reading and teach them to generate information which contributes to their learning from text.

There is an introduction to the reading skill strategies necessary to work place. John (1992:39) emphasizes on the teachers' role responsive teaching as opposed to the traditional practice of recitation characterized by the teachers' questions, the students' responses, and the teachers' evaluation.

It had long been interesting in the process of teaching reading practice of traditional practice by asking students questions before, during and after reading skills. In responding to reading text, the students have to formulate their own questions. The purpose of such process is to help the students to acquire the schema of reading that acknowledges their intention and then encourages the dynamic interaction between the reader and the author.

Associated with some views of reading, it is a model of comprehension process focused on psycholinguistic thought. Clark and Clark (1977:165) state that the processing of the bottom up, we would identify the word and person in the suitable places according to the context of the sentences. In the bottom up processing the starting point is the text itself. It is also in the teaching reading. The students attend to the individual word and the structure in the text.

The useful source on the reading skill has a large collection of exercises dealing with specific skills like deducing the meaning and use unfamiliar lexical items through understanding word formation and developing words comprehension speed. In this case, the teacher could give more exercises to the students of one skill such as formation by translating through contextual meaning developing the word meaning.

According to Cooper (2000:134), teaching reading skill is challenging because there is so much knowledge that we have gained over the decades and knowing how to use this knowledge becomes critical. It is controversial, especially at the beginning levels of instruction. Much of the controversy about beginning reading has focused around phonics and decoding and how reading should be taught. With all the knowledge we have, there are still many questions that we are unable to answer. As we know, teachers usually had a single book that they used in teaching reading, sometimes teachers grouped students and had different students reading in different levels of book. In teaching reading the teachers need a variety of types of texts.

Reading comprehension has several definitions. They are as follow; reading is a systematic process for the students to learn, so they face different problems when reading in English. However, the problems vary according to assisting the construction of meaning and comprehension. This is to ensure that the students build confidence and interest about reading.

Wixson (1987:71) describes reading is the process of constructing meaning from written text. It is a complex skill requiring the coordination of number of interrelated sources of information and the process of constructing meaning through the dynamic interaction among the readers exiting 
knowledge; the information suggested by the text being read; and the context of reading situation.

Nunan (1991:17) said that reading is a process of decoding written symbols, working from smaller units (individual letters) to larger ones (words and sentences). So, reading activity is very useful for the students although they do not know the meaning of the materials they read. Perhaps, the students just read without knowing the meaning of what they read. In reading activity, it emphasizes not only on the reading practice but also on the comprehending a reading passage. To increase the quality of reading, either in pronunciation, fluency, etc, students need to deal with the reading practice. To obtain information and idea, on the other hand, the students have to deal with the reading comprehension.

Reading is techniques for improving student's success in extracting useful knowledge from text. Reading comprehension is understanding a text that is read, or the process of "constructing meaning" from a text. Comprehension is a construction process because it involves all of the elements of the reading process working together as a text read to create a representation of the text in the reader's mind. Reading comprehension is said to be an activity of associating or connecting a reader's ideas or thoughts with what an author states in print. When a reader or student encounters a reading, he tries to associate his prior knowledge and what has purposefully written in print. If this happen, it can be said that reading conveys comprehension.

Vacca, et al (1991:172) states that without comprehension, the end of reading is an empty, vacuous event. Anderson, et al says (2003:98) that it is an incorrect use of the word read when one reads a passage but he does not understand it. Gelinkoff (2001:90) states that there are three main components of reading comprehension such as decoding, lexical access (having a meaning for printed word in ones memory), and text organization (obtaining meaning from units larger than single word). Of the components proposed, it can be inferred that the following sub skills are gained as a consequence of reading printed language, i.e. recalling word meanings and drawing inferences about a word from context; getting the literal sense of details and weaving together ideas in content; drawing inferences form the content' and recognizing the author's purpose, attitude, tone, mood and techniques. Olson and Diller (2000:40) describe reading comprehension as a term to identify the skills such decoding ability, knowledge of vocabulary presented, familiarity with concept, and the cognitive development needed to understand and apply the information contained within written material. Both of them said that it is difficult to precisely reading comprehension of printed material. Basically they depend on the characteristic of the texts and the reader itself.

According to Kustaryo (1998:11), reading with comprehension is an understanding about what has been read. It is an active thinking process that depends not only on comprehension skills but also on the student's experiences and prior knowledge. Comprehension involves understanding the vocabulary, seeing the relationships among words and concepts, organizing ideas, recognizing the author's purpose, making judgments, and evaluating.
When dealing with comprehension of any printed materials, a reader will engage with word recognition skill, the most important factors in determining the degree of comprehension, and specific comprehension skills such as skimming, scanning, interference, etc.

From the above explanation, it can be summed up comprehension is very essential in reading process. Someone does not really read if he or she does not understand what is being read, even if he or she can pronounce the world perfectly. Reading comprehension means comprehending or understanding new information and ideas presented in the printed page and utilizing them as the application of interaction between the reader and the author.

\section{Cooperative Integrated Reading and Composition (CIRC)}

This cooperative learning model was developed by Slavin in 1980s and his associates for reading and writing in the elementary grades. There, students are assigned to teams composed of members of different reading groups where pairs of students from two different groups formed together. In this model, a team might be composed of two students from the top reading group and two from the low reading group and the instruction is directed by the teacher.

During working in group of reading task, for instance, students are doing variety of activities like reading quietly to one another, making prediction, practicing spelling and vocabulary, and writing about what they have read. The test is given after the students work in team and the team that meets the criteria will get the certificate. Stated that in Margarita, et al (1997:2) Cooperative Integrated Reading and Composition (CIRC), students are assigned to four-member heterogeneous learning teams. Following a lesson, students work in their teams on a variety of cooperative activities including partner reading, identification of main story elements, vocabulary and summarization activities, practice of reading comprehension strategies, and creative writing and using a process writing approach.

Steven, et al as quoted by Margarita, et al (1997:5) Cooperative Integrated Reading and Composition consists of variety of instructional practices which develop social, academic, and communication skills. The CIRC program consists of three principal elements: direct instruction in reading comprehension, Treasure Hunt (story-related activities) activities, and integrated language arts and writing. Treasure Hunts are worksheets that include comprehension questions, prediction guidelines, new vocabulary to be learned, story retell, story-related writing suggestions. In all of these activities, students work in four-member heterogeneous learning teams. All activities follow a series of steps which involve teacher presentation, team practice, independent practice, peer pre-assessment, additional practice, and test. Students are encouraged to cooperate and help one another, because students' scores on individual assessments are summed to form team score.

Robinson (1991:4) relatedly said there are composed with vocabulary words, and a word list the student reads aloud to the teacher. Teams receive their points from the individual 
scores received by students on tests and from writing assignments. Based on the definition CIRC is a comprehensive program to teach reading and writing.

\section{The Procedures of Cooperative Integrated Reading and Composition}

Stevens-Slavin (1987:118) says Cooperative Integrated Reading and Composition is a model that can be used in teaching reading comprehension. In this model have some ways in learning process. There are:

a. The teacher makes group the member consist of four persons from the heterogeneous group or mixed ability group.

b. The teacher gives the text or clipping that suitable with the topic.

c. Students read and work together to find out the main idea, give the suggestion for the text, and write down on the paper.

d. Presenting the result of the group.

e. The teacher gives the supporting or gives solution to the students.

f. The teacher and students make the summary. Slavin (2008:201-204). Cooperative Integrated Reading and Composition is focused on the reading whereas the students work together in team and the teacher has to control in order to reach the objective of reading comprehension, vocabulary and spelling. The students are expected to work together with other.

The primary elements of CIRC are:

a. Group of reading. The students share in two or three people for a group based on the level of the students' ability in reading.

b. Team. The students placed in pairs or trio in reading group. Then, the students work in pairs one pairs has the highest level in reading and the second pairs have the lowest level. If one of them gets the score, they are a super team.

c. The activities deal with story. The students have the reading text or novel. The text or novel is read in group and discussed. In this activity the teacher explains the objective of reading, introduce the new vocabulary and after the students read and then discuss about the text.

d. Pair reading. The students read the story by silent and then they read loud and his/her friends listen and correct it.

e. Writing. The students are given a text, they read the text and then they write what they have read about character, background of the event, and the problem in the passage.

f. Vocabulary. They can look for the new words, they read the words loudly and they know the meaning of the words.

g. Retell. After they read and discuss the text, they have to tell to their friend.

h. Test. The students are given the comprehension test of the story. They write the sentences based on the text. In this test they may not help each other

\section{METHOD}

\section{Research Design}

The experimental research is used in this study. The research design used was quasi-experimental research. The design of this study involved two unit of the third semester of english department at IAIN Lhokseumawe.

\section{Population and Sample}

The population of this research was all the third semester of english departemet at IAIN Lhokseumawe. It consist of 63 students. The samples was chosen by using random sampling. Unit-2 as experiemental group and Unit-1as control group.

\section{RESULT AND FINDING}

The descriptive statistics were calculated to achieve the results of pre-test and post-test of the experimental group and the control group. It was found that students' reading scores in the experimental group are better understanding in reading comprehension. Table 1 and 2 shows that the scores the post-test are higher than those of the pre-test.

As it can be seen in the Table 3, the mean score of the pretest in the control group is higher than that of in the experimental group. However, significant different average scores of these need to be tested again. For the purpose of the test of homogeneity of variance test using the Levenetest. The test result can be seen in the following table:

Based on the table above it can be seen that the significant score is 0.247 and the significance $\geq$ is 0.05 , the null hypothesis is accepted. Subsequent, it needs to be tested the different average score of both groups by analyzing variances, the result of calculated can be seen in the following Table 4:

Table 1. Descriptive statistics of the control and experimental groups' performance on reading comprehension pretest

\begin{tabular}{lcccc}
\hline Groups & Mean & N & $\begin{array}{c}\text { Standard } \\
\text { deviation }\end{array}$ & $\begin{array}{c}\text { Standard } \\
\text { error mean }\end{array}$ \\
\hline Control & 65.45 & 32 & 9.541 & 1.687 \\
Experimental & 61.45 & 31 & 8.286 & 1.488 \\
\hline
\end{tabular}

Table 2. Descriptive statistics of the control and experimental groups' performance on reading comprehension posttest

\begin{tabular}{lcccc}
\hline Groups & Mean & N & $\begin{array}{c}\text { Standard } \\
\text { deviation }\end{array}$ & $\begin{array}{c}\text { Standard } \\
\text { error mean }\end{array}$ \\
\hline Control & 76.09 & 32 & 10.297 & 18.20 \\
Experimental & 81.45 & 31 & 8.869 & 1.593 \\
\hline
\end{tabular}

Table 3. Test of homogeneity of variances

\begin{tabular}{lccc}
\hline Levene statistic & df1 & df2 & Sig. \\
\hline 1.366 & 1 & 61 & 0.247 \\
\hline
\end{tabular}


Table 4. The homogenity test of mean in the experimental group and the control group

\begin{tabular}{lccccc}
\hline & Sum of square & Df & Mean square & F & Sig \\
\hline Between groups & 316.860 & 1 & 316.860 & 3.959 & 0.051 \\
Within groups & 4881.552 & 61 & 80.025 & & \\
Total & 5198.413 & 62 & & & \\
\hline
\end{tabular}

Form the table above $\mathrm{F}_{\text {score }}$ obtained 3.959 with significance of 0.051 and the significance $\geq$ is 0,050 . The null hypothesis is accepted. It can be concluded that the data was homogeneous, and it meant two groups had the same ability.

Further the frequency of the final test score data in the control group can be seen in the following Table 5:

The data above shows that the percentage of the result score in the control group. In the post-test most of students got high score, 8 students obtained 80 or $25.0 \%$. The students got under the average were 17 students or $53.1 \%$, they obtained score 75 , and the students got above the average were 15 students or 46.9 .

\section{Prerequisites test analysis}

Before the data were analyzed using t-test the first data from each group must meet the requirements of homogeneity and normality of variance.

\section{Homogeneity test}

Homogeneity test tested based on the result of the post-test in the experimental group and the control group conducted with Levene test, the result calculation can be seen in the following Table 6:

Based on the table above it can be seen that the score of significant is 0.607 and the significance $\geq$ is 0.05 , the null hypothesis is accepted. It showed that both of groups had the same variance.

\section{Normality test}

Normality test was conducted by using statistical Kolmogorov Smirnov, the result can be seen in the below Table 7:

The table above showed that significance of Kolmogorov Smirnov of the experimental group and control group is 0.056 and 0.157 . This significance is bigger than the significant level 0.05 or $0.056 \geq 0.05$, so the null hypothesis is accepted. On the other words, the data for experimental group and the control group had normal distribution of data.

\section{Hypothesis testing}

After prerequisites test analysis of homogeneity variance of data and normality data were fulfilled, then the analysis can be continued. The hypothesis testing in this research used Student Technique analysis. As for the result of student test was presented in the following Table 8:

Based on the table above, the writer intends to discuss the result of the test (pre-test and post-test) given to both groups for validity of research finding. The discussion will be guided by the summary of the research finding.
Table 5. Frequency of the post-test data in the control group

\begin{tabular}{lcccc}
\hline & Frequency & Percent & $\begin{array}{c}\text { Valid } \\
\text { percent }\end{array}$ & $\begin{array}{c}\text { Culmulatif } \\
\text { percent }\end{array}$ \\
\hline Valid 55 & 1 & 3.1 & 3.1 & 3.1 \\
60 & 2 & 6.3 & 6.3 & 9.4 \\
65 & 4 & 12.5 & 12.5 & 21.9 \\
70 & 4 & 12.5 & 12.5 & 34.4 \\
75 & 6 & 18.8 & 18.8 & 53.1 \\
80 & 8 & 25.0 & 25.0 & 78.1 \\
85 & 3 & 9.4 & 9.4 & 87.5 \\
90 & 2 & 6.3 & 6.3 & 93.8 \\
95 & 1 & 3.1 & 3.1 & 96.9 \\
100 & 1 & 3.1 & 3.1 & 100.0 \\
Total & 32 & 100.0 & 100.0 & \\
\hline
\end{tabular}

Table 6. Homogeneity test variance data in experimental group and control group

\begin{tabular}{lccc}
\hline Levene statistic & df1 & df2 & Sig. \\
\hline 0.267 & 1 & 61 & 0.607 \\
\hline
\end{tabular}

\section{Hypotheses prove in this reseach are:}

1. $\mathrm{H}_{0}$ there is not a significant difference in achievement between the students who are taught through Cooperative Integrated Reading and Composition from those are taught through traditional approach.

2. Ha: there is significant difference in achievement between the students who are taught trough Cooperative Integrated Reading and Composition from those who are taught through traditional approach.

Based on the table above it can be seen that $\mathrm{t}_{\text {score }}$ assumed that score variance is not the same or not homogenous was 2.210 and score significant was 0.031 . The score significant $\leq 0.05$, so the null hypothesis was rejected and alternative hypothesis was accepted. It meant the students were taught by CIRC was significant difference in achievement between students who were taught through traditional approach.

It indicated that there was significance different between both of the result of the test. This meant that implementing CIRC technique in teaching reading comprehension was better than the traditional method. This also the proof that the hypothesis of this experimental study is true that there is a significant between the post-test result of both group and CIRC technique is better than traditional method in teaching reading. It can be said CIRC technique teaching is a good alternative than traditional one in teaching reading comprehension. In the other words, CIRC technique provided more significant result than those used in the control group.

In this analysis, the writer can show some results of previous studies that related to CIRC technique such as Mubarok, H \& Sofiana, N. (2017) the effect of CIRC on 
Table 7. Normality test in the experimental group and the control group

\begin{tabular}{lllllllll}
\hline & Group & \multicolumn{2}{c}{ Kolmogorov-Smirnov (a) } & & \multicolumn{3}{c}{ Shapiro-Wilk } \\
\cline { 3 - 4 } \cline { 7 - 9 } & & Statistic & df & Sig. & & Statistic & Df & Sig. \\
\hline The result of learning & Experimental & 0.155 & 31 & 0.056 & & 0.941 & 31 & 0.085 \\
& Control & 0.133 & 32 & 0.157 & & 0.975 & 32 & 0.655 \\
\hline
\end{tabular}

a: Lilliefors Significance Correction, Ho: Normal Distribution of Data

Table 8. Analysis of student test

\begin{tabular}{|c|c|c|c|c|c|}
\hline & \multicolumn{2}{|c|}{$\begin{array}{c}\text { Levene's test for } \\
\text { equality of variances }\end{array}$} & \multicolumn{3}{|c|}{ t-test for equality of means } \\
\hline & $\mathbf{F}$ & Sig. & $\mathbf{T}$ & Df & Sig. (2-tailed) \\
\hline \multicolumn{6}{|l|}{ The result of learning } \\
\hline Equal variances assumed & 0.267 & 0.607 & 2.210 & 61 & 0.031 \\
\hline Equal variances not assumed & & & 2.215 & 60.187 & 0.031 \\
\hline
\end{tabular}

the experimental group performed better on reading ability than the control group. Zarei (2012) investigated the effects of the 'Student Teams-Achievement Divisions' (STAD) and 'Cooperative Integrated Reading and Composition' (CIRC) cooperative learning models in reading achievement and vocabulary learning of Iranian learners of English. Lina Murti (2011) found that CIRC technique in teaching learning had proved that CIRC technique was effective in improving students' reading ability in narrative texts. The influence of CIRC technique was addressed by the increase of the score throughout $\mathrm{t}$-score that was $\mathrm{t}_{\text {hitung }}=2,082>\mathrm{t}_{\text {tabel }}=2,002$, it means Ha was accepted and CIRC can influence of students' ability in narrative text.

Eti Suhartini (2012) found that in teaching writing argumentation text through CIRC model, the students improve in writing argumentation text. The result of the score got throughout $\mathrm{t}$-score that was $\mathrm{t}_{\text {hitung }}=11.15>\mathrm{t}_{\text {table }}=2.021$. so the hypothesis was accepted. Based on the result of some previous studies and this research, the writer can conclude that CIRC technique is an appropriate model used in teaching-learning process. Because in CIRC technique has steps in learning process, there are; first, the teacher makes a group for every group consists of four persons by heterogeneous or mixed ability. Second, the teacher gives the text or clipping that are suitable with the topic. Third, students read and work together to find out main idea, give the suggestion about the text and they write on the paper. Fourth, they present the result of their group. The finally, the teacher gives the supporting or solution to the students and make the summary about the text. In learning process of CIRC technique every students need another to discuss, and the teacher gives the change for every members to share, help and solve the problem faced in their group. Because all students have to be responsible with their task and they may give the same contribution. But sometimes some of them cannot express their idea in group discussion. By working together they can increase their ability in learning reading comprehension, because they need with others and they can share with their friends in group. Furthermore, in processing work together in group the students can obtain the feedback for each member in the group, they have an opportunity to improve their skill in learning reading comprehension. On the other hand, the students cannot get any information in their learning process because they do not study in their group or they do not work together. It means that learning together in a group can give a good contribution for each member in group.

\section{DISCUSSION}

The study was aimed to investigate the development of students' reading ability by using a CIRC technique. To find the result of students' development in reading ability, the writer focused on the effect of CIRC activities in teaching reading comprehension. A pre-test was given for both groups at the first meeting. The students were given a different handout of the text. They were asked to read the text carefully and answer the questions. After conducting the pre-test the writer discussed and explained the text. The teacher did not give any motivation or strategy at this point. Since the students did not have any preparation for their reading test, they could not answer well. The result of the pre-test for both groups varied with the range of low-middle and high level.

Next meeting, the writer started the treatment of teaching reading through CIRC technique in the experimental group. Here, the teacher grouped students into seven groups and arranged four persons for each group, the students have different abilities. Then the teacher gave the different text to each group. Every group read and worked together with their friends in group and the students had to read that text. After reading the text, they discussed and write down their opinion about main idea, vocabulary and summary from the text.

Later, each group was asked to present the result of discussion from each group in front of class. After each group presented the materials, the teacher gave supporting or solution if the students had some problems in discussing. The last, the teacher and students took the summary of the text, because every text that had been read should understand and it has a lesson for the reader. It is appropriate with the theory stated by Margarita (1997:6) students learn how to solve problems, study together, help each other, solicit opinions, present rationales, defend, synthesize, listen to others, and ask relevant questions. This treatment was given until 4 meetings. 
After a series of treatment, students seem to have more vocabularies than ever before particularly related to the materials given. The students could get new vocabularies because here the writer treated them in reading by providing new vocabularies, how to pronounce the words when they read the text. In the control group students were taught by a traditional method. The teacher was not asked to give any treatment as the writer did to the experimental group.

On the last meeting, the post-test was conducted. Both classes were given the same test. After analyzing of the data result, it shows that distribution of the experimental group and control score on the pre-test scores were homogenous. The homogeneity of variance was calculated after finding out that the pre-test data of the experimental and the control group. Based on the pre-test score was found that $\bar{x}=61.45$ and $\mathrm{s}_{1}^{2}=8.286$ are for experimental group and $\overline{\mathrm{x}}=65.94$ and $\mathrm{s}_{2}^{2}=9.541$ are for control group.

Form the table above $\mathrm{F}_{\text {score }}$ obtained 3.959 with significance 0.051 and the significance $\geq 0.050$. The null hypothesis is accepted. It can be concluded that the data was homogeneous, and it meant two groups had the same ability.

From Kolmogorov Smirnov of experimental group and control group is 0.056 and 0.157 is $0.056 \geq 0.157$ is bigger than significant level 0.05 , so the null hypothesis is accepted. Another word, the data for the experimental group and control group had normal distribution.

The two groups were significantly different after having received the treatment in several meetings. Attaining the post-test score signifies that the post-test scores showed that the distribution of both groups is normal. The result of t-score showed that the experimental group is better than the control group. The data proved that as the calculated score is higher than the value of t-table $(2.210>0.031)$. The result is $t_{\text {test }}>t_{\text {table }}, \mathrm{H}_{0}$ or the null hypothesis was rejected and $\mathrm{Ha}$ or the alternative hypothesis was accepted. It indicates that there was a significant different between both test result. This meant that the implementation of CIRC technique in teaching reading comprehension was better than traditional method because the students can help each other. As Mubarok, $\mathrm{H}$ \& Sofiana, N (2017) in CIRC by having the students work in small groups, it helps the students to accomplish their assignments more quickly. The result of this study showed that the t-score was higher than the t-score of some previous researches. But Eti Suhartini's research got the highest t-score.

Based on the result of students' performance in reading comprehension the writer had conducted the research in the experimental group and the control group. Each group had the prêt-test and post-test. The pre-test in the control group was higher than that of the experimental group. However, after the teacher taught them in four meetings and the last meeting students was given post-test for both groups. The students of experimental group got higher scores than control group.

Basically, the students' ability of the experimental group before treatment is almost the same with the students of control group in answering the questions. It was proven from the pre-test of the experimental group and the control group.

The students' ability in learning reading comprehension is still lack of vocabulary, they have difficulty to understand the words or expressions in the text and they not only have difficult in comprehending the words but also have difficult in comprehending the specific information from the text. In this case, when the teacher taught by using CIRC technique in some meetings, the students began to know and understand how to determine a topic and a main idea from the text. In addition, they recognize about reference terms that it is pronoun reference related with student's ability to replace a word in the text.

\section{CONCLUSSION AND SUGGESTION}

\section{Conclusion}

Based on the findings, the researcher puts some conclusions as follow:

1. The data analysis shows that the mean score of the posttest was higher than that of the pre-test. The score in the experimental group is higher than that of the control group. It means that score variance is not the same or not homogenous was 2.210 and score significant was 0.031 . The significant is smaller 0.05 . This proves that $\mathrm{H}_{0}$ is rejected and $\mathrm{H}_{\mathrm{a}}$ accepted. It indicates the students were taught by using CIRC was significant difference in achievement between students who were taught through a traditional method.

2. By using CIRC technique in the experimental group, the situation in this group was very enjoyable, the students can communicate with each other freely and they were more enthusiastic when they were joining in this group. The writer had observed that the reading comprehension scores of the experimental group students were higher than those of the students taught through a traditional method.

3. Students in cooperative groups receive encouragement and support from their more competent peers than use the traditional method in class teaching

\section{Suggestion}

For future studies, the researcher are needed some suggestions in order to make reading become an active and have a meaningful activity. The English teacher should use various and appropriate strategies or techniques such as CIRC in the process of teaching reading comprehension

\section{REFERENCES}

Arikunto, S. (2006). Prosedur Penelitian: Suatu Pendekatan dan Praktek, Jakarta: Rineka Cita.

Clark, D., and Clark, D. (1977). Reconsidering Research on Learning from Media. Review on Education Research, 53, 445-460.

Cooper, J. David. (2000). Literary Helping Children Construct Meaning. Boston: Houton Miffin. http:// slpgsd-blogspot.com/2010/01/model-pembelajaran-cooperative html (online), access 16-6-2011http://wywid. wordpress.com/2009/11/10/model-pembelajaran-23-cooperative-integrated-reading, access 23-5-2011 http:// 
respository.upi.edu/operator/upload/s-ing-054760chapter2.pdf,16-9-2011 http:/www.promising practices.net/program.asp? programid=142, 16-9-2011

John, AP. (1992). Transforming Ideas for Teaching and Learning to Read. Washington: Office of Educational.

Margarita C., et,al., (1997). Effects Of Bilingual Cooperative Integrated Reading and Composition On Students Transitioning From Spanish To English Reading, Report No. 10. The Center for Research on the Education of Students Placed At Risk (CRESPAR): U.S Department of Education (R-117-D40005)

Mubarok, H \& Sofiana, N. (2017). Cooperative Integrated Reading and Composition (CIRC) and Reading Motivation: Examining The Effect on Students' Reading
Ability. Lingua Cultura, 11(2), 121-126. http://dx.doi. org/10.21512/lc.v11i2.1824 Slavin, E. Robert. (2005). Evidence-Based Reform: Advancing the Education of Students at Risk. Johns Hopkins University. A National Task Force on Public Education: Center for American Progress.

Slavin, E.R. (2008). Cooperative Learning, Teori, Riset dan Praktik. Bandung.

Stevens., Robert, et al, (1987). Cooperative Integrated Reading and Composition, Jokes Hopkins University.

Sudjana, F. (1996). Metoda Statistik. Bandung: Tarsito.

Zarei, A.A. (2012). The Effects of STAD and CIRC on L2 Reading Comprehension and Vocabulary Learning. Frontiers of Language and Teaching, 3(5), 161-173. 